Гриненко О. І., к. військ.н., доцент;

Кутовий О. П., к.т.н., с.н.с.;

Шапталенко М. І., к.т.н., доцент

Центр воєнно-стратегічних досліджень Національного університету оборони України імені Івана Черняховського, Київ

\title{
Аналіз правових основ стратегічного керівництва силами оборони сектору безпеки і оборони України
}

Резюме. У статті проведено аналіз діючої нормативно-правової бази України у сфері стратегічного керівництва силами оборони сектору безпеки і оборони України. Сформульована необхідність та напрями подальшого удосконалення правового поля держави.

Ключові слова: стратегічне керівництво силами оборони; сектор безпеки і оборони.

Постановка проблеми. Питання стратегічного керівництва силами оборони сектору безпеки і оборони (далі - СБО) України на сьогодні потребує грунтовного аналізу та подальшого глибокого удосконалення. Особливо щодо його органу управління та самого механізму управління силами оборони СБО України.

Аналіз останніх досліджень i публікацій. У діючій нормативно-правовій базі ці питання висвітлені без відповідної конкретики та багатоваріантності, що дає змогу неправильної трактовки їх положень.

Ще гірше стоїть питання стратегічного керівництва силами оборони СБО України, якщо заходи, які передбачені діючою нормативно-правовою базою, виконані частково. А саме, 3 початком часткової мобілізації та ведення антитерористичної операції (далі - АТО), тобто 3 початком особливого періоду, воєнний стан не було введено і Генеральний штаб Збройних Сил України (далі - ГШ ЗС України) не був задіяний як Ставка Верховного Головнокомандувача (далі - Ставка ВГК) робочий орган Верховного Головнокомандувача ЗС України. Це істотно вплинуло на якість керівництва силами оборони в ході проведення АТО, особливо в питаннях координації спільних дій сил $\mathrm{i}$ засобів різних відомств. Тому, логічно постає питання аналізу діючої нормативно-правової бази та підготовки пропозицій 3 iї удосконалення. [4, 6].

Метою статті $\epsilon$ формулювання пропозицій до змін нормативно-правових документів, особливо щодо стратегічного керівництва силами оборони сектору безпеки i оборони в особливий період.
Виклад основного матеріалу. У Конституції України зазначено, що оборона України, захист іiї суверенітету, територіальної цілісності та недоторканності покладаються на 3С України. А у статті 106 розділу 5 Конституції України визначено, що Президент України очолює Раду національної безпеки i оборони (далі - РНБО) України і, як Верховний Головнокомандувач (далі - ВГК) 3С України здійснює керівництво у сферах національної безпеки і оборони держави.

Також ВГК вносить до Верховної Ради України (далі - ВР України) подання про оголошення стану війни та, у разі збройної агресії проти України, приймає рішення про використання ЗС України та інших військових формувань, про загальну або часткову мобілізацію та введення воєнного (надзвичайного) стану в Україні або в окремих iii місцевостях у разі загрози нападу або небезпеки державній незалежності України, для подальшого затвердження цих рішень ВР України [1].

У положеннях Конституції України немає ні слова як про сектор безпеки і оборони, так i про механізм стратегічного керівництва його силами і засобами.

Із аналізу Закону України "Про правовий режим воєнного стану”, особливо статті 5 цього закону про порядок введення воєнного стану, можна дійти висновку про неузгодженість пунктів 3 та 4.

3 пункту 3, Указ Президента України про введення воєнного стану в Україні або в окремих іiі місцевостях, затверджений Верховною Радою України, підлягає негайному оголошенню через засоби масової інформації або оприлюдненню в інший спосіб. Очевидно, що він уже затверджений ВР України. А в пункті 4 зазначено, що у разі оголошення указу 
Президента України про введення воєнного стану в Україні або в окремих іiі місцевостях ВР України збирається на засідання у дводенний строк без скликання та розглядає питання щодо затвердження указу Президента України про введення воєнного стану в Україні або в окремих іiі місцевостях у порядку, встановленому Конституцією України та Регламентом ВР України. Отже виходить, що вже затверджений та оголошений указ Верховна Рада України знову затверджує своїм складом у дводенний строк та оголошує його.

Для виправлення такої суттєвої розбіжності достатньо 3 пункту 3 видалити фразу “затверджений Верховною Радою України”. Тоді всі пункти статті 5 набирають логічного сенсу [2].

Ще менше про стратегічне керівництво силами оборони СБО України викладено в Законі України "Про оборону України". Зокрема, в статті 6 розділу 2 сказано, що Президент України видає укази i розпорядження, а ВГК ЗС України - видає накази і директиви з питань оборони.

У статті 8 цього закону зазначено, що Ставка ВГК створюється для забезпечення стратегічного керівництва 3С України, іншими військовими формуваннями та правоохоронними органами і що в особливий період може створюватися Ставка ВГК, як вищий колегіальний орган воєнного керівництва обороною держави у цей період.

Президент України вводить в дію своїм Указом пропозиції, які РНБО України подає на його розгляд, про утворення Ставки ВГК, iї персонального складу та граничної чисельності [3].

Зі змісту Закону України "Про оборону України” видно, що до питання стратегічного керівництва силами оборони СБО України додалося лише положення, що для забезпечення стратегічного керівництва ЗС України, іншими складовими сил оборони в особливий період може створюватися Ставка ВГК, як вищий колегіальний орган воєнного керівництва обороною держави у цей період. На сьогодні має місце колізія, коли 3 оголошенням Президентом України часткової мобілізації почався особливий період, а Ставка ВГК створена не була і зовсім не врегульовано законодавством, яким чином буде здійснюватися стратегічне керівництво силами оборони СБО України в особливий період за даних умов.

У Тимчасовій доктрині підготовки $\mathrm{i}$ застосування 3С України, інших військових формувань та органів спеціального призначення (далі - ОСпП) про стратегічне керівництво силами оборони сказано (п. 232, 2-35), що в особливий період, керівництво ЗС України, ІВФ та ОСпП Президент може здійснювати через Ставку ВГК, як вищого колегіального органу воєнного керівництва обороною держави, робочим органом якої $\epsilon$ Генеральний штаб.

У Воєнній доктрині України (п. 25) показаний механізм залучення інших складових СБО.

Президент України приймає рішення щодо застосування (залучення) ЗС України, Державної служби спеціального зв'язку та захисту інформації України, Державної спеціальної служби транспорту, інших складових сил оборони в разі зовнішньої агресії, внутрішнього збройного конфлікту чи масштабних проявів тероризму. А об'єднаний комітет з питань розвідувальної діяльності при Президентові України забезпечуватиме координацію діяльності розвідувальних органів України у відповідних сферах (п. 40).

Проте велику плутанину вносять інші положення цієї доктрини, де сказано, що матеріально-технічну базу системи управління СБО України становитимуть: Головний ситуаційний центр України, мережа відомчих ситуаційних центрів, ресурси Антитерористичного центру при Службі безпеки України, Головного центру управління службою Державної прикордонної служби України, аналогічних підрозділів інших складових СБО, які будуть реформовані 3 метою досягнення більш високого рівня взаємодії (п. 35).

При цьому, передбачається розширення можливостей Головного ситуаційного центру України для забезпечення координації $\mathrm{i}$ контролю діяльності інших складових СБО в мирний час, в особливий період, в умовах воєнного, надзвичайного стану i при виникненні кризових ситуацій, що загрожують національній безпеці України. (п. 39) [4].

До питання стратегічного керівництва силами оборони СБО України додалося лише положення, що матеріально-технічну базу системи управління СБО Украйни чомусь становитимуть Головний ситуаційний центр України i мережа відомчих ситуаційних центрів. Однак, як відомо, ситуаційні центри не $\epsilon$ органами військового управління, а лише аналітичними органами.

Тобто на них покладаються лише функції забезпечення координації i контролю діяльності органів виконавчої влади, 
правоохоронних органів та військових формувань у сфері національної безпеки i оборони в мирний час, в особливий період, в умовах воєнного, надзвичайного стану і при виникненні кризових ситуацій, що загрожують національній безпеці України.

У Стратегічному оборонному бюлетені 2016 року частково піднімаються питання реформування системи управління силами оборони СБО. Зокрема в розділі 2 йдеться про систему управління силами оборони, що Міністр оборони обіймає найвищу цивільну посаду в МО України та відповідає за формування політики держави у сфері оборони, оборонне планування, програмний та ресурсний менеджмент, всебічне забезпечення життєдіяльності, функціонування, розвиток та застосуванням 3С України.

А начальник Генерального штабу Головнокомандувач 3С України $є$ найвищою військовою посадовою особою в державі, підпорядкованою Президенту України та Міністру оборони України. Через ГШ ЗС України він здійснює управління ЗС України та координацію і контроль за виконанням завдань у сфері оборони органами виконавчої влади, органами місцевого самоврядування та силами оборони.

Цим визначенням відповідає модель стратегічного керівництва силами оборони, яка наведена на рис. 1.

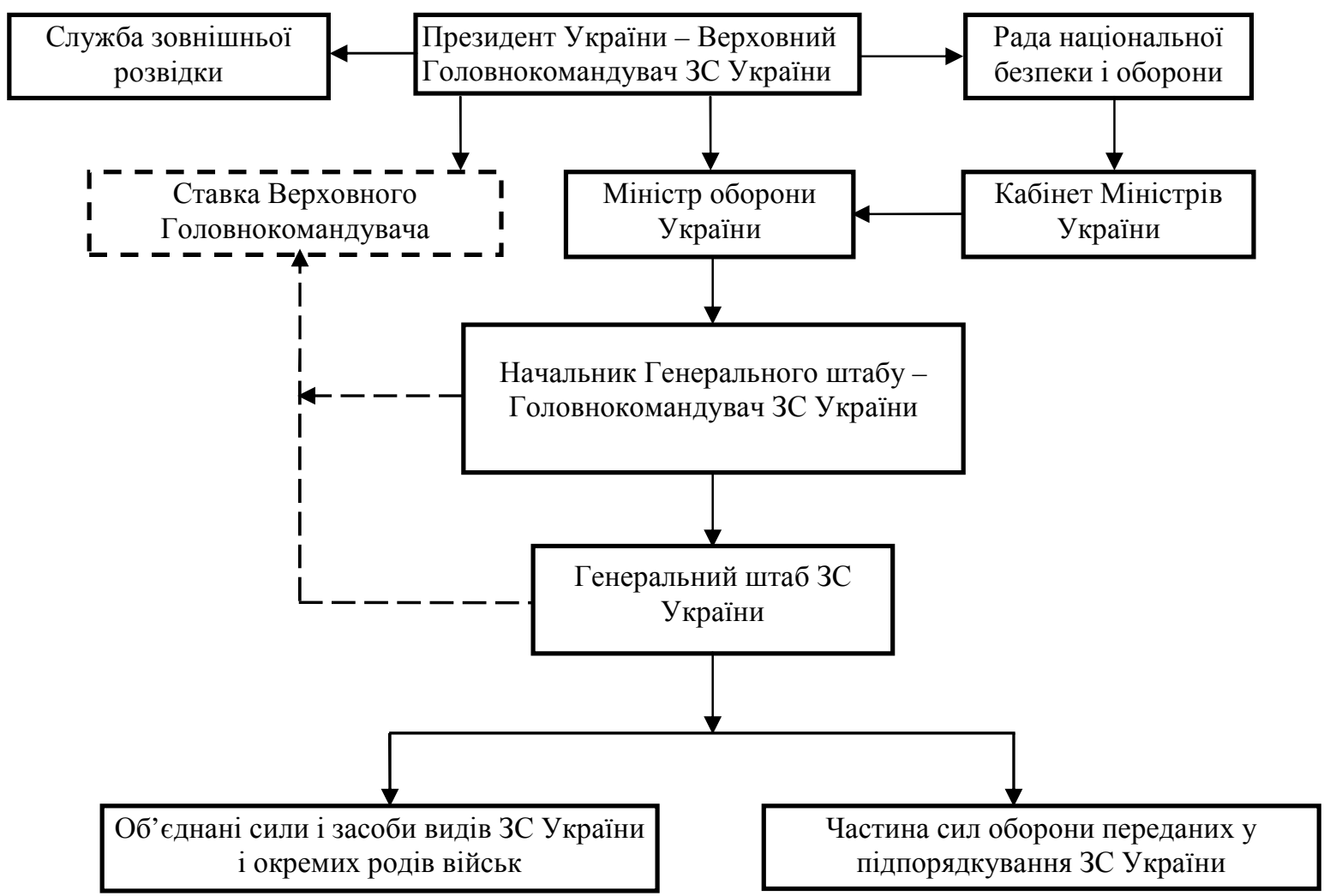

Рис. 1. Модель стратегічного керівництва силами оборони України (діюча)

Планується до 2020 року ввести окремі посади - "Головнокомандувач Збройних Сил України" та "Начальник Генерального штабу Збройних Сил України" (нині ці посади об'єднані). Це може відбутися раніше за умови зниження рівня воєнної загрози національній безпеці України (завершення в Україні особливого періоду).

До 2020 року планується відокремити функції формування, підготовки та розвитку військ (сил), які покладаються на ГШ i командування видів (окремих родів військ) 3С України, від функцій застосування переданих у підпорядкування військ (сил), які здійснюватиме Об'єднаний оперативний штаб (далі - ООШ) 3С України.

Неясним також $\epsilon$ положення, що $\mathrm{y}$ перспективі планується інтегрувати ГШ ЗС України в МО України. В Україні було прикладено значних зусиль щодо їх роз'єднання, а нині прийдеться робити зворотні зусилля з їх об'єднання?

Головнокомандувач (далі - ГК) ЗС України буде найвищою військовою посадовою особою, підпорядкованою Президенту України та Міністру оборони України. На нього покладатиметься вся повнота повноважень щодо управління ЗС України. Він відповідатиме за готовність до виконання 
покладених

завдань,

управління

застосуванням 3С України та переданих в його підпорядкування сил i засобів інших складових сил оборони.

Командувачі видів (окремих родів військ) ЗС України підпорядковуватимуться ГК ЗС України та відповідатимуть за розвиток підпорядкованих їм військ (сил), їхнє технічне оснащення та всебічне забезпечення, підготовку та готовність до виконання покладених завдань, управління ними під час проведення видових операцій (силами та засобами відповідного виду або окремого роду військ).

Начальник ГШ ЗС України підпорядковуватиметься ГК ЗС України та відповідатиме за виконання завдань і функцій, покладених на ГШ ЗС України, у тому числі щодо визначення вимог до спроможностей сил оборони, потреб у ресурсах, необхідних для належного виконання завдань 3С України та іншими складовими сил оборони, стратегічного планування застосування та розвитку ЗС України, їх технічного оснащення, підготовки та всебічного забезпечення.

Командувач об'єднаних сил підпорядковуватиметься ГК ЗС України та здійснюватиме через ООШ ЗС України планування застосування та безпосереднє управління об'єднаними силами і засобами 3С України, які передані в його підпорядкування, та інших складових сил оборони [6].

Цим визначенням відповідає модель стратегічного керівництва силами оборони, яка наведена на рис. 2.

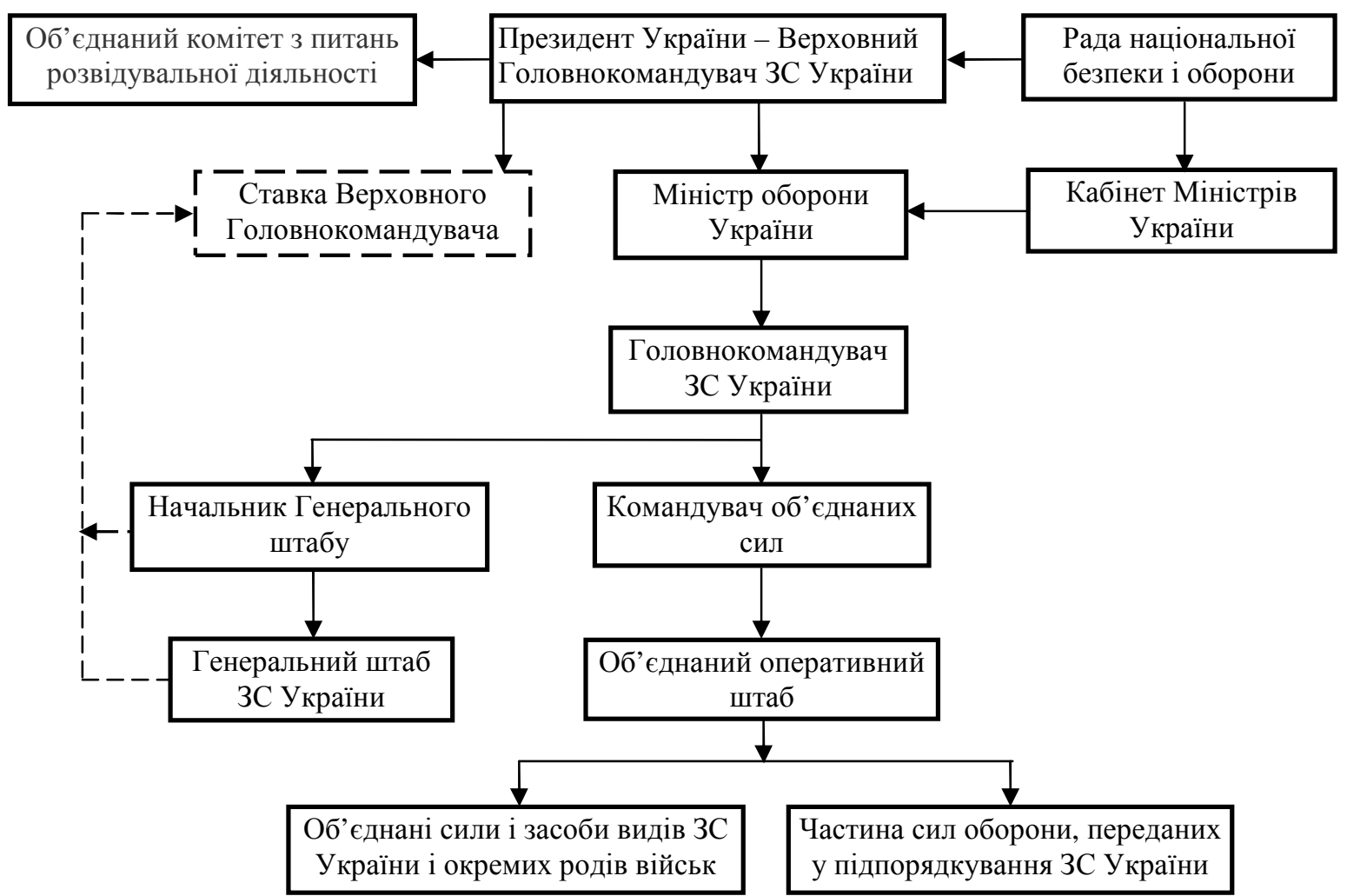

Рис. 2. Модель стратегічного керівництва силами оборони України (2020 р.)

Із положень Стратегічного оборонного бюлетеня видно, що розписана лише вертикаль керівництва силами оборони через Міністра оборони i начальника ГШ ЗС України, але сам механізм стратегічного керівництва СБО, частиною якого $є$ сили оборони, не розписаний.

У пункті 3 розділу 2 Концепції розвитку СБО України дається оцінка стану складових СБО. Слід зазначити, що сучасний стан складових СБО не дає змоги забезпечити гарантоване реагування на актуальні загрози національній безпеці України.
Нерозв'язаними проблемами в СБО залишаються:

у положеннях Конституції України немає ні слова як про сам сектор безпеки і оборони, так і про механізм стратегічного керівництва його силами і засобами;

недостатній рівень координованості керівництва складовими СБО;

у разі відсутності Ставки ВГК не визначений орган управління (механізм) вдосконалення консолідованого розвитку та посилення відповідних оперативних спроможностей складових СБО; 
у нормативно-правових документах не визначений механізм стратегічного керівництва силами оборони СБО, якщо 3 оголошенням часткової мобілізації Президентом України почався особливий період, а Ставка ВГК, робочим органом якої $є$ Генеральний штаб, не була створена;

матеріально-технічну базу системи управління сектором безпеки i оборони України не може становити Головний ситуаційний центр України і мережа відомчих ситуаційних центрів, в силу того, що вони не $\epsilon$ органами військового управління, а лише аналітичними органами;

не зрозуміле положення, що у перспективі планується інтегрувати Генеральний штаб Збройних Сил України в Міністерство оборони України, в силу того, що були прикладені значні зусилля для їх роз'єднання, а зараз прийдеться робити зворотні зусилля;

у інших складових сил оборони запасів ракет, боєприпасів та інших МТЗ для своїх сил i засобів, які беруть участь у відбитті агресії, просто немає, запаси для них у 3С України не передбачалися, оскільки бюджетні витрати по відповідних статтях державного бюджету виділялися не на МО України, а на саме ці ж відомства сил оборони СБО України.

Висновок. Подолати зазначені проблеми передбачається шляхом цілеспрямованого реформування та розвитку СБО із запровадженням уніфікованої системи планування та управління ресурсами на основі сучасних європейських та євроатлантичних підходів, що дасть змогу підвищити його інституційну та структурну збалансованість i створити ефективний комплексний та багатофункціональний державний інструментарій забезпечення національної безпеки.

Подальші дослідження доцільно зосередити на удосконаленні стратегічного керівництва силами оборони СБО. Особливо складним i не повністю узгодженим залишається нормативно-правова база 3 питань всебічного забезпечення інших складових сил оборони (крім 3С України) під час проведення операції об'єднаних сил.

\section{СПИСОК ВИКОРИСТАНОЇ ЛІТЕРАТУРИ}

1. Конституція України від 28.06.1996 (редакція станом на 30.09.2016).

2. Закон України від 12 травня 2015 року № 389-VIII “Про правовий режим воєнного стану".

3. Закон України від 06.12.1991 № 1932-XII “Про оборону України".

4. Воєнна доктрина України. Указ Президента України від 24.09.2015 № 555/2015.

5. Стратегічний оборонний бюлетень 2016: Реформування системи управління силами оборони.

6. Концепція розвитку сектору безпеки і оборони України. Указ Президента України від 14.03.2016 № 92/2016.

Стаття надійшла до редакції 13.10.2017

Гриненко А. И., к.воен.н., доцент;

Кутовой О. П., К.т.н., с.н.с.;

Шапталенко Н. И., к.т.н., доцент

Центр военно-стратегических исследований Национального университета обороны Украины имени Ивана Черняховского, Киев

\section{Анализ правовых основ стратегического руководства силами обороны сектора безопасности и обороны Украины}

Резюме. В статье проведен анализ действующей нормативно-правовой базы Украины в сфере стратегического руководства силами обороны сектора безопасности и обороны Украины. Сформулирована необходимость и направления дальнейшего усовершенствования правового поля государства.

Ключевые слова: стратегическое руководство силами обороны; сектор безопасности и обороны.

A. Grinenko, PhD (Military);

O. Kutoviy, PhD (Technical);

N. Shaptalenko, PhD (Technical)

Center for Military and Strategic Studies of the National Defence University of Ukraine named after Ivan Cherniakhovskyi, Kyiv

Analysis of legal frameworks of the strategic managing forces of defensive of sector of safety and defensive of Ukraine

Resume. In the article the analysis of operating normatively-legal base of Ukraine is conducted in the field of the strategic managing forces of defensive of sector of safety and defensive of Ukraine. A necessity and directions of further improvement of the legal field of the state is formulated.

Keywords: strategic managing forces of defensive; sector of safety and defensive. 